\title{
Recreation of a central element of the structure of spiritual buildings in Odesa - Transfiguration cathedral in 1991-2010
}

Summary

The article presents the main stages of an outstanding lost object of Ukrainian cultural heritage recreation - Transfiguration cathedral in Odesa in 1999-2010.

Key words: spiritual structure of the city, lost object of cultural heritage, history of cathedral recreation

Odesa has always been an international city, it was being built by famous architects from various countries. Polish architects Felix Gonsiorowski, Mykola Tolwinski, Piotr Ambrozhewich, Lew Wlodek and others made a significant contribution into shaping the city construction. A lot of majestic buildings, which are now under state protection as architecture and city-planning monuments, were created by their projects and with their participation. The following three objects of spiritual purpose occupy special place among thos builing: Cathedral of the Blessed Virgin Mary - the main Roman Catholic temple in Blese (irchitects Frase Ki, second half of 19 h centich

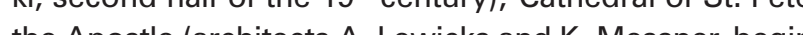
the Aposte (archists A. Lewicks Candr. Messner, begin-

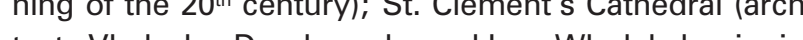
tects Vladyslaw Dombrovsky and Lew Wlodek, beginning

They were a part of the construction network which formed the spiritual structure of Odesa at the begin ning of the $20^{\text {th }}$ century. The centre of this structure - Transfiguration Cathedral was founded at the sam time as Odesa - in 1774 - and for over a hundred years was developing together with the city and at the beginning of the $20^{\text {th }}$ century it became the biggest cathedral of the North-Western Black Sea region - the centre of spiritual life for Odesa residents. Barbarously ruined in 1936, the Cathedral was reconstructed by the will and efforts of Odesa residents at the begin ning of the $21^{\text {st }}$ century (pic. 2) without involvement of budgetary costs [1].

In 1991 I was teaching at Architecture faculty of Odesa Engineering and Construction institute. It was at that time that we conducted architectural search and started developing the first version of recreating the Transfiguration Cathedratin Odesa project. Architectura measurements, done by Odesa Engineering and Construction institute students in 1936 under the supervision of an engineer F. Motsakov and available at that moment iconography from a number of sources in Odesa, Kyiv and Saint Petersburg served as the basis for developing the project.

At that time my friend and colleague V. Proskuriakov, who worked as a teacher at Architecture faculty of Lviv Polytechnic National University, came to Odesa We visited Soborna square where the cathedral had been located before 1936, he got acquinited with historical documents with regards ruined saced place, support the imporance the topic of recreating the main city cathedrat and haviced to sidy the aspect of is ciy-shaping role in the structure of spint of bulding in Oding role the basis of an architectural yantra method. In March 1993 I prepared the first edition of ground ing the need for recreating the cathedral where framed the hypothesis that Transfiguration Cathedral in the hypothesis that Transfiguration Catheture and its was the central element of city struca pecolits sacred buildings (pic. 3) which created a pecular network (pic. 4), covered Odesa and shaped the spirituality of its residents. Having los the whole elenent of this network

Recreation of a lost main cathedral of the city was expected to assist in revival of its residents' spirituality which, in its turn, would lead to improvement of Odesa residents' life quality. Moreover, geometrical analysis of significant buildings location regular- iffif
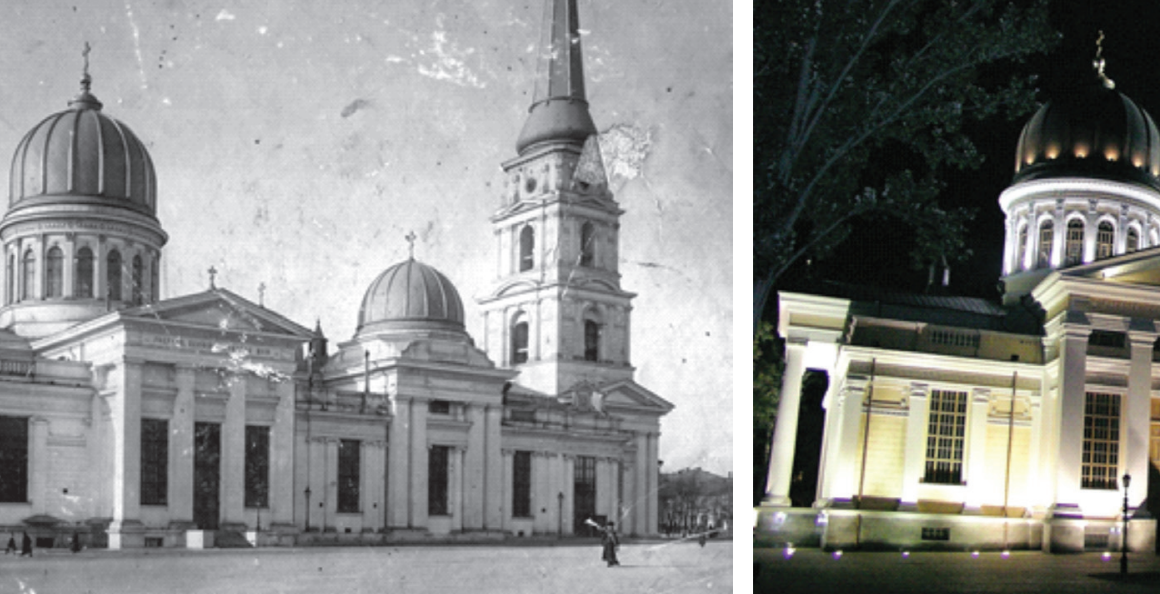

ill. 1. TheCathedralafterreconstruction, 1900-1903. From the archives of architect Volodymyr Meshcheryakov
ill. 2. Cathedral's background lighting re-created, 2005. From the archives of architect Volodymyr Meshcheryakov

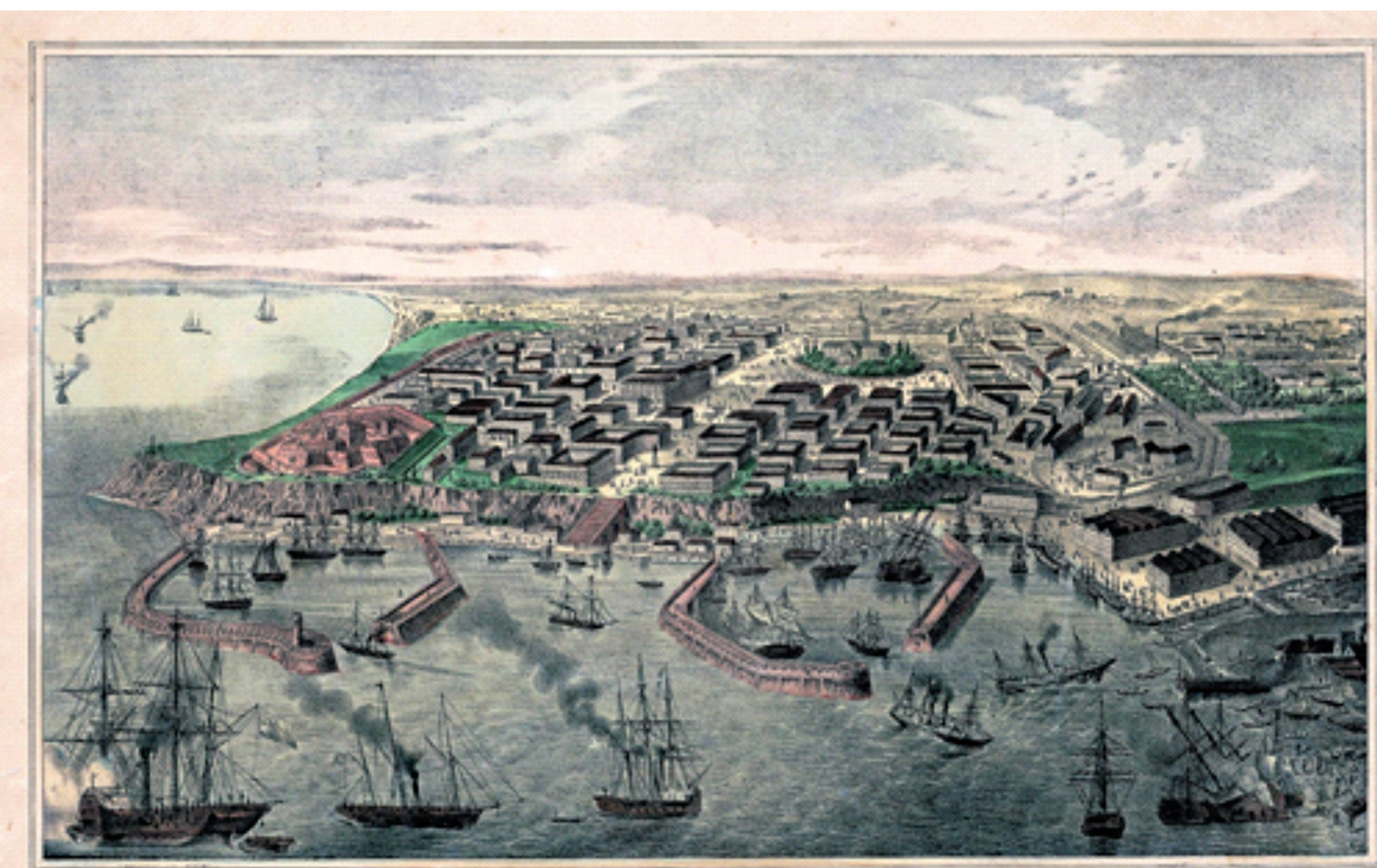

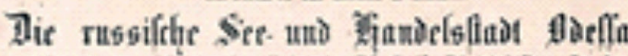

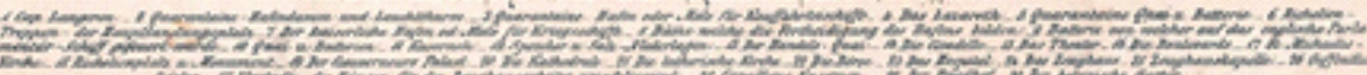

- The Hebrew University of Jerusalem \& The Jewish National \& University Library

ill. 3. Mid-nineteenth century
Volodymyr Meshcheryakov

ity with Transfiguration Cathedral in Odesa being a central element of the structure (pic. 4) could become the basis for choosing the locations of new sacred objects in the places of crossing the lines where similar buildings were absent. Therefore, the structure of significant buildings in Odesa could continue being sufficiently developed. The suggested scheme should be combined with geology data, tectonic and geographical features of city territory, it should use the data of psychics and folk methods of identifying the "sacred places" what was not done by us at that time.

In 1994 my two diploma students Liudmyla Shamarina and Anna Yaroshenko, graduates of the Architecture faculty of Odesa Engineering and Construction institute (now Odessa State Academy an integrated diploma project of recreating Odesa Transfiguration Cathedral which can be considered of Civil Engineering and Architecture), defended 


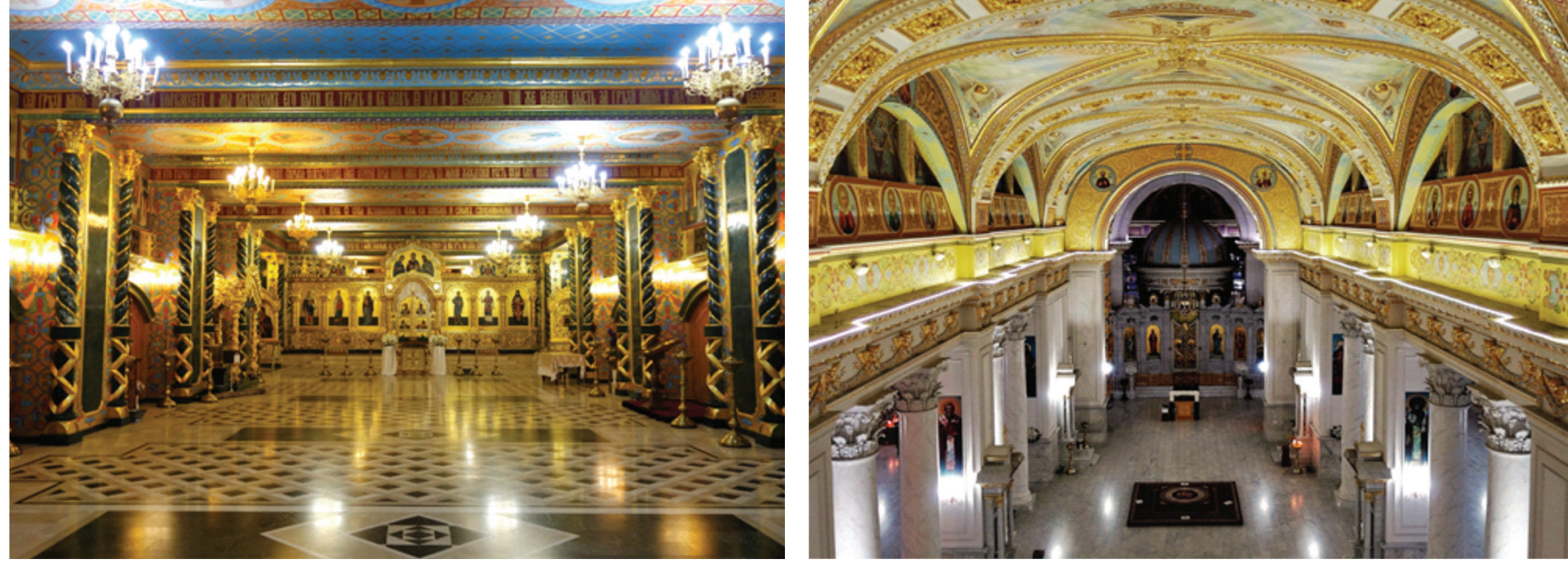

ill. 5. TheUnderneathTemple. 2005. From the archives of architect Volodymyr Meshcheryakov
ill. 6. The Upper Temple of the Transfiguration Cathedral. From the archives of architect Volodymyr Meshcheryakov

ited places with a special status, first and foremost in the places where it is necessary to recreate traditional character of historical environment of the most signifcant period in its development.

While designing research and project documentation for recreating the sacred place we had a task to desigh pr recreating the sacred place wre the a talk to design plans, proportions and sithoue we the building as precisely as poss bous correspond to the parades and incriors which would correspond to the parameters and appearance of an outstanding lost object of cultural hertage as closely as possib. For achiev of culs goal we have applied the comparison method of objective available information with project solutions, in particular - remains of historical foundations and iconography.

As for correspondence of plans project solutions for recreated cathedral to its ruined prototype, with the help of an electronic tacheometer we have conducted the measurements of bare foundations remains for comparing their metrical parameters with project solutions of the plans. Later, we have layered the developed by us project plan of the cathedral first floor on these measurements with its following adjustments according to foundation fragments silhouette of a historical building. That way we have achieved the correspondence between a recreated object and its ruined prototype on the plan.

In 2000 photogrammetric reconstruction of the cathedral bell tower facades was done, as a result of which high points of a designed object were identified preciseIy, in particular - cathedral bell tower spire. Its height at the point of a cross reached 77 meters, not 75,7 meters as it was measured before destroying the cathedral in 1936 by the students of Odesa Engineering and as it was mesuren F.V. Motsakov [2].

On the basis of designed and agreed in established order built in 2000 . While comparing the available height

The history of my personal participation in reconstruction of Transfiguration cathedral in Odesa consists of five main stages:

1. Collection of initial data, under my supervision development of a complex diploma project at the architecture faculty of Odesa State Academy of Civil Engineering and Architecture (1993), its finishing to the stage of a sketchy project and defense at city building board of architecture management and city planning of Odesa city council (1994-1995):

2. Designing a competition project and victory at an open all Ukrainian competition concerning ment - Transfiguration cathedral in Odes (1999);

3. Designing a sketchy project and its defense at scientifically-methodical council of State building of Ukraine (1999-2003);

4. Making work documentation and building the cathedral complex (1999-2005):

5. Designing interior projects of the underneath and upper temples of the cathedral, Andriivsky hall (refectory), christening rooms and their implementation (2003-2010).

BIBLIOGRAPHY

[1]V. Meshcheriakov. The reconstruction of the Transfigured Savior
Cathedral in Odessa, Ukraine [Text]: Monograph/- Odessa: Feniks, 2017-464 p.: il.
[2] Students Projects of Odessa Transfiguration Cathedral Re-crea-
tion / Volodymyr Meshcheriakov - Architectural studies / AS 2017 .
Volute 3 . parameters of a constructed bell tower, project solutions have been corrected in a number of height marks of the Cathedral. reconstruction of an outstanding lost monuguests of Odesa as emperors, official and non-official figures, artists, travellers. In 2004 Bulgarian Prime MinIster, tsar Simeon II of Bulgaria (as Bulgarian citizen Simeon Borisov Sakskoburggotski) with his wife visited the Council of Europe Parliament Assembly - René van der Linden with his wife.

The chronology of a real recreation of an outstanding lost monument of Ukraine - Odesa Transfiguration Ca-

While forming research and project documentation our priority was city-planning and environmental types of recreating the object as a lost valuable element of architecturally-historical environment. This type of recreation allows grounded changes to architecturally-planning or decorative-artistic solutions of the prototype with the aim of taking into consideration modern demands in a part of constructions, decorative materials, engineering supapplied on valuable territories of historical inhab- 